\title{
Effect of Quenching Rate and Pre-strain on the Strain Ageing Behaviors of 7075 Aluminum Alloys
}

\author{
Ramazan Kaçara ${ }^{a *}$ Kemal Güleryü̈z \\ ${ }^{a}$ Technology Faculty, Manufacturing Engineering Department, Karabük University, 78050, \\ Yüzüncüyll, Karabük, Turkey \\ ${ }^{b}$ Technical Education Faculty, Karabuk University, 78050, Yüzüncüyll, Karabuk, Turkey
}

Received: July 7, 2014; Revised: March 9, 2015

\begin{abstract}
The mechanical properties of aluminum alloys are strongly dependent on the thermo-mechanical process so, the strain ageing behavior of $7075 \mathrm{Al}$-alloy was investigated in this study. A set of test pieces was solution heat treated at $480^{\circ} \mathrm{C}$ for $2 \mathrm{~h}$, water quenched (SHTWQ) then pre-strained for $8 \%$ in tension. The test samples were aged at $140^{\circ} \mathrm{C}$ for $0.5,1,2,3,4,6,8,10,12,24,48,72$ and $96 \mathrm{~h}$ in a furnace. The other set of test samples were solution heat treated at $480^{\circ} \mathrm{C}$ for $2 \mathrm{~h}$, quenched in sand (SHTSQ) then pre-strained for $8 \%$ in tension. They were also aged at $140{ }^{\circ} \mathrm{C}$ for same intervals. The effect of strain ageing, on the mechanical properties of Al-alloy, was investigated by mean of hardness, and tensile tests. The results shown that, the quenching rate after solution heat treatment, ageing time and temperature, as well as pre-strain, play a very important role in the precipitationhardening associated with ageing process of the 7075 Al-alloy.
\end{abstract}

Keywords: static strain ageing, Al-alloys, pre-strain, quenching rate, ageing time

\section{Introduction}

7000 series aluminum alloys have been widely used for aeronautical applications due to their desirable mechanical properties such as; high strength and low density ${ }^{1-3}$. The high strength aluminum alloys are therefore an exceptional material for energy absorption ${ }^{4}$.

The 7000 series aluminum alloy is known as "heat treatable alloys ${ }^{4}$. The mechanical properties of these alloys are strongly dependent on the thermo-mechanical process and it is therefore important to understand the relationship between the microstructure evolution during thermomechanical processing and the mechanical properties. The 7075 aluminum alloy is strengthened by precipitation hardening. The precipitation hardening involves raising the temperature of the alloy into a single phase region where all precipitate dissolve. The alloy is then rapidly quenched to form a supersaturated solution ${ }^{5,6}$. Afterwards, the artificial aging is generally carried out at temperatures up to approximately $200{ }^{\circ} \mathrm{C}^{[7-11]}$. The usual precipitation sequence of the 7000 series Al-alloys can be summarized as: solid solution - GP zone-metastable $\eta$-stable $\eta\left(\mathrm{MgZn}_{2}\right)^{[12]}$. For the peak aged (T6) 7000 series aluminum alloys, the $\eta$ phase is the main precipitate; however, for the over aged temper (T7 $\times$ ) the $\eta$ phase is the main precipitate ${ }^{13}$.

This paper is conducted with the objective of investigating the effect of pre-strain, quenching rate and aging time on the mechanical behavior of the $7075 \mathrm{Al}$-alloys. The paper focused mainly on examining the changes in the tensile and yields strength, hardness of 7075 aluminum alloys when heat treated at $140{ }^{\circ} \mathrm{C}$ for different aging times.

*e-mail: rkacar@karabuk.edu.tr

\section{Materials and Experimental Procedure}

The T6 heat treated commercially available 7075 Al-alloy used in this study is a plate with a thickness of $10 \mathrm{~mm}$. The chemical composition of 7075 alloys is given in Table 1.

The standard tensile test pieces (ASTM E8M-09) ${ }^{14}$ $5,7 \mathrm{~mm}$ in diameter with a gauge length of $36 \mathrm{~mm}$ were machined from the as-received blanks (Figure 1).

In order to maintain the super saturated solid solution at room temperature, the $7075 \mathrm{Al}$-alloy test pieces, after the heat treatment in a furnace for $2 \mathrm{~h}$ at $480+/-2{ }^{\circ} \mathrm{C}$ and quenched in water (SHTWQ) or in sand (SHTSQ) were kept in a freezer to prevent natural aging.

The tensile test pieces (SHTWQ/SHTSQ) were pre-strained for $8 \%$ in tension. The amount of pre-strain to which each specimen was sustained was measured by marking a gauge length of $36 \mathrm{~mm}$ on the specimen and straining until this gauge length had extended to $38.88 \mathrm{~mm}$ for $8 \%$ pre-strain. After the process of SHTWQ/SHTSQ and pre-straining, the specimens were artificially age hardened at $140{ }^{\circ} \mathrm{C}$ for a period of $0,5,1,2,4,6,8,10,12,24,36,48,72$ and 96 hours in a furnace and subsequently cooled in air. Finally, they were tested in tension at room temperature using a Schimadzu tensile testing machine at a crosshead speed of $2 \mathrm{~mm} \cdot \mathrm{min}^{-1}$. Triplicate samples were used per run in order to correct for minor differences in experimental conditions.

A hardness measurement test was also employed to investigate the mechanisms responsible for strain aging. The hardness measurement of aged test samples was carried out using a Universal type Hardness (HRB) instrument. Five hardness readings were performed per sample. The HRB hardness result were converted and given as $\mathrm{HV}_{5}$

The fractured surfaces of as-received, SHTWQ and SHTSQ \& $8 \%$ pre-strained aged test pieces were also analyzed 
Table 1. The chemical composition of 7075 Aluminum alloys ( $\%$ weight).

\begin{tabular}{cccccccc}
\hline $\mathrm{Si}$ & $\mathrm{Fe}$ & $\mathrm{Cu}$ & $\mathrm{Mn}$ & $\mathrm{Mg}$ & $\mathrm{Cr}$ & $\mathrm{Zn}$ & $\mathrm{Ti}$ \\
0.057 & 0.276 & 1.402 & 0.011 & 2.38 & 0.201 & 6.029 & 0.078 \\
$\mathrm{~B}$ & $\mathrm{Na}$ & $\mathrm{Ca}$ & $\mathrm{Ni}$ & $\mathrm{Pb}$ & $\mathrm{P}$ & $\mathrm{Sn}$ & $\mathrm{Co}$ \\
0.001 & 0.002 & 0.005 & 0.003 & 0.002 & $<0.0002$ & 0.0002 & 0.0003 \\
$\mathrm{~V}$ & $\mathrm{Sb}$ & $\mathrm{Sr}$ & $\mathrm{Be}$ & $\mathrm{Hg}$ & $\mathrm{Zr}$ & $\mathrm{Bi}$ & $\mathrm{Li}$ \\
0.001 & 0.0007 & 0.0001 & 0.0008 & 0.0006 & 0.0008 & $<0.0002$ & $<0.0001$ \\
$\mathrm{Cd}$ & $\mathrm{Ga}$ & $\mathrm{Ag}$ & $\mathrm{As}$ & $\mathrm{Al}$ & & & \\
0.0004 & 0.007 & 0.0002 & $<0.0005$ & 89.5 & & & \\
\hline
\end{tabular}
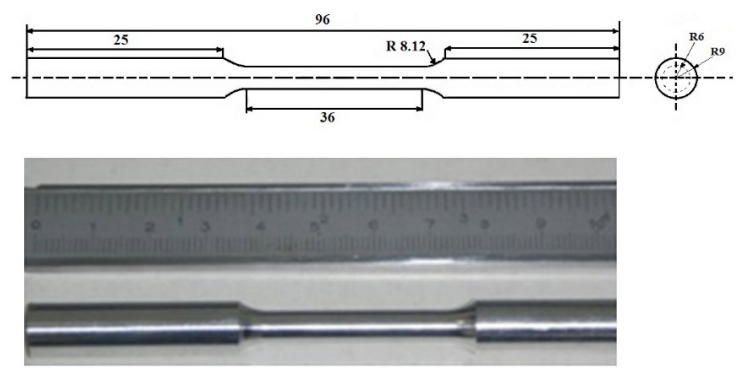

Figure 1. The tensile test sample.

using scanning electron microscope (SEM). Representative $\mathrm{X}$ specimens were sectioned from fractured tensile samples and mounted for scanning electron microscopy (SEM) investigation.

\section{Results and Discussions}

The SHTWQ and SHTSQ \& 8\% pre-strained test pieces were age hardened at $140{ }^{\circ} \mathrm{C}$ for $0.5,1,2,3,4,6,8,10,12$, $24,36,48,72$ and $96 \mathrm{~h}$; to study the effect of quenching rate and heat treatment on the tensile strength, yield strength, percentage elongation and hardness of 7075 Al-alloy. The results of the mechanical properties of aged 7075 Al-alloy are presented in Figures 2-5.

The ultimate tensile and yield strength (UTS and YS) for the specimens exposed at $140^{\circ} \mathrm{C}$ for different soaking times plus $8 \%$ pre-strained are shown in Figure 2 for SHTWQ and SHTSQ. It can be observed that as the aging time increases for the ageing temperature of $140^{\circ} \mathrm{C}$, a continuous increase in tensile strength and yield strength is noticed. Maximum tensile strength and yield strength are observed when the alloy is aged between 1 and $12 \mathrm{~h}$ at $140{ }^{\circ} \mathrm{C}$ for SHTWQ \& $8 \%$ pre-strained test samples. However, maximum tensile strength and yield strength are determined when the alloy is aged between 1 and $10 \mathrm{~h}$ at $140{ }^{\circ} \mathrm{C}$ for SHTSQ \& $8 \%$ pre-strained test samples (Figure 2). Further increases in the aging time for $140{ }^{\circ} \mathrm{C}$ has reduced the tensile strength and yield strength of the $7075 \mathrm{Al}$-alloy under conditions of SHTWQ \& 8\% pre-strained and SHTSQ \& 8\% pre-strained. However, the $\%$ elongation fracture in $7075 \mathrm{Al}$-alloy generally falls gradually with increase in time at $140{ }^{\circ} \mathrm{C}$ (Figure 3). The aged specimens have shown the ductility of $19.9 \%$ for SHTWQ and $16 \%$ for SHTSQ test pieces when precipitation hardened at $140{ }^{\circ} \mathrm{C}$ for 12 or $10 \mathrm{~h}$ respectively.

An increase in tensile strength and yield strength but a decrease in percentage elongation could be explained

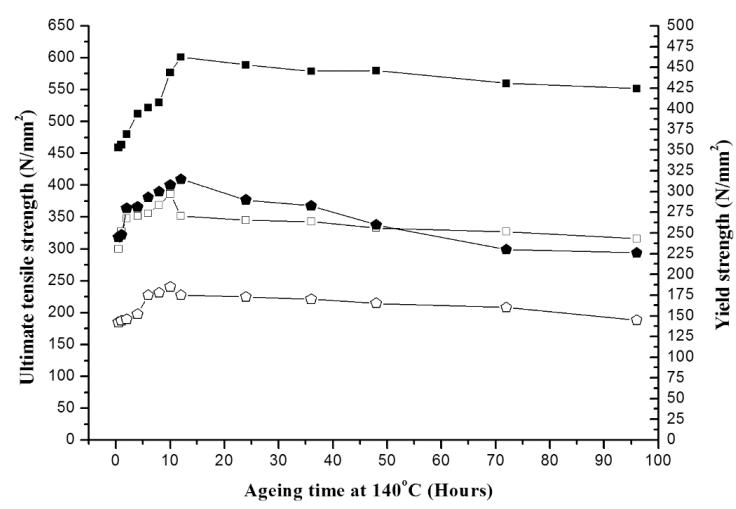

$\neg$ Ultimate tensile strength SHTSQ $-0-$ Yield strength SHTSQ

$\longrightarrow$ - Ultimate tensile strength SHTWQ $\longrightarrow$ - Yield strength SHTWQ

Figure 2. The relationship between ageing time and UTS and yield strength for SHTWQ and SHTSQ \& 8\% pre-strained test samples aged at $140{ }^{\circ} \mathrm{C}$.

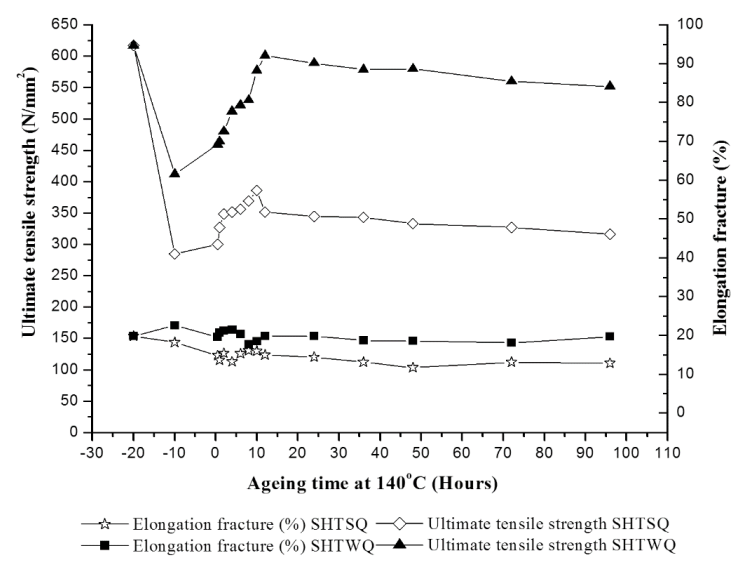

Figure 3. The relationship between ageing time and UTS and elongation fracture for SHTWQ and SHTSQ \& 8\% pre-strained test samples aged at $140{ }^{\circ} \mathrm{C}$.

by a diffusion assisted mechanism, and also by hindrance of dislocation by impurity atoms, i.e. foreign particle of a second phase, since the material after quenching from $480^{\circ} \mathrm{C}$ (solution heat treatment) will have excessive vacancy concentration ${ }^{6,12,13}$. Rafiq et al. ${ }^{15}$ showed that as the aging time and temperature increases, the density of GP zones will also increase. The GPI zones are stable around $115^{\circ} \mathrm{C}$. The GPII zones are stable around $150^{\circ} \mathrm{C}$. Holding the temperature at $125^{\circ} \mathrm{C}$ for 20 hours the GPII zones are transformed to the metastable $\eta$ precipitates and will further on be transformed 
to stable $\eta\left(\mathrm{MgZn}_{2}\right)$ precipitates in the region of $200{ }^{\circ} \mathrm{C}^{[16]}$. Hence, the degree of irregularity in the lattices will cause an increase in the mechanical properties of the Al-alloy.

In this study, the hardness, yield and tensile strength of the SHTWQ and SHTSQ sample increased by ageing time up to $12 \mathrm{~h}$ and 10 hours respectivelly (Figures 4 and 5). Sha and Cerezo are reported that the metastable $\eta$ phase which has got lameller morphology responsible for incresing hardening effects in the aged 7075 alloy $^{12}$. The strengthening effect of 7075 Al-alloy could be also explained as a result of interference with the motion of dislocation due to the presence of foreign particle of any other phases (metastable $\eta$ or stable $\eta\left(\mathrm{MgZn}_{2}\right)^{[16]}$. The metastable $\eta$ phase could be responsible for increased hardening ${ }^{16}$.

The strengthening effect of 7075 Al-alloy could also be explained as a result of the intermediate plastic deformation which increases the ageing rate and improves strength reached by conventional ageing by providing homogeneously distributed nucleation sites for precipitation in the matrix. Cassada et al. ${ }^{17,18}$ demonstrated that increasing high levels of plastic deformation prior to artificial aging for a near 2090

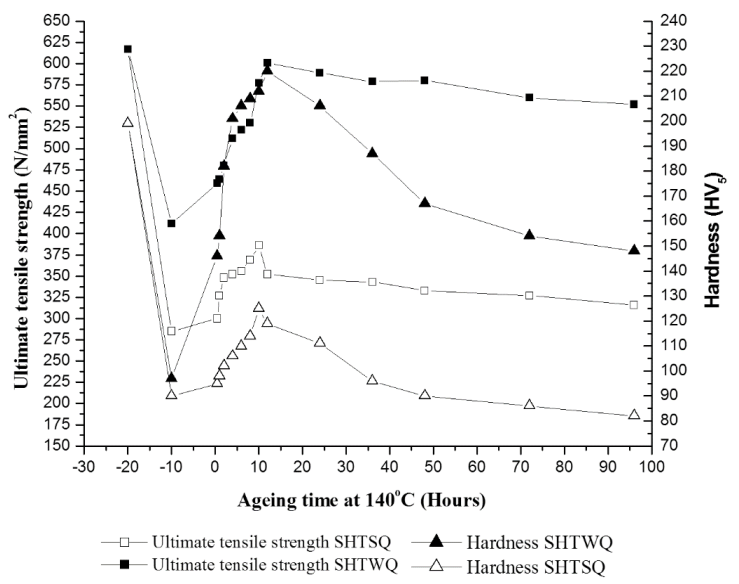

Figure 4. The relationship between ageing time and UTS and hardness for SHTWQ and SHTSQ \& 8\% pre-strained test samples aged at $140{ }^{\circ} \mathrm{C}$.

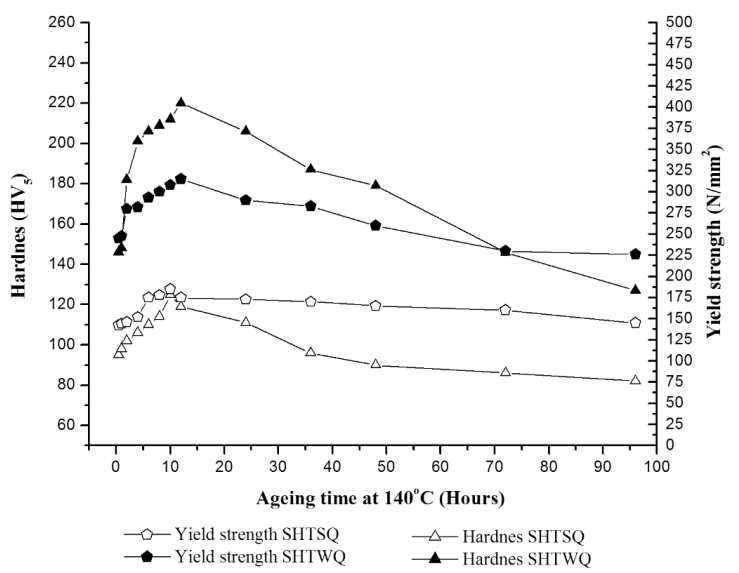

Figure 5. The relationship between ageing time and hardness and yield strength for SHTWQ and SHRSQ \& $8 \%$ pre-strained test samples aged at $140{ }^{\circ} \mathrm{C}$.
Al-alloy aged at $190{ }^{\circ} \mathrm{C}$ resulted in marked gains in yield strength for the under and peak aged conditions due to the enhanced volume fraction of fine matrix precipitates such as $\mathrm{Al}_{2} \mathrm{CuLi}$. Matrix precipitation of this more abundant and finer strengthening phase directly correlates to the increased strength of the material versus a non-stretched condition that exhibits only grain boundary precipitation ${ }^{19}$. Since the deformation prior to ageing creates more nucleation sites for precipitates, the higher strength of pre-strained and aged sample (SHTWQ and SHTSQ) can be attributed to the presence of homogenously distributed precipitates in the matrix.

In this study, a EDS analysis was carried out on the formation of second phase particle in the SHTSQ and SHTWQ aged samples at the temperature of $140{ }^{\circ} \mathrm{C}$ for 10 and 12 hours ageing times respectively. EDS analysis results from Figure 6 indicate that the formed precipitates contain a high amount of $\mathrm{Cu}$ and $\mathrm{Zn}$, but less $\mathrm{Al}$ and $\mathrm{Mg}$ as compared with matrix chemical composition. These precipitates are responsible for static strain hardening.

Further increase in the ageing time for $140^{\circ} \mathrm{C}$ decreases the tensile strength, and yield strength of the alloy. Srivatsan and Sriram reported that the formation of stable $\eta$ phase $\left(\mathrm{MgZn}_{2}\right)$ decreases to the yield and tensile strength and hardness ${ }^{20}$. The stable $\eta$ phase $\left(\mathrm{MgZn}_{2}\right)$ for its own crystal structure related to the ageing time, so the coherency between the precipitates and aluminum matrix disappears. As a result of this, the distortion in the crystal structure of aluminum alloys decreases, so the dislocation motion occurs easily, hence the tensile strength of over aged sample decreased.

The relationship between hardness, UTS and yield strength is illustrated in Figure 4 and Figure 5 respectively
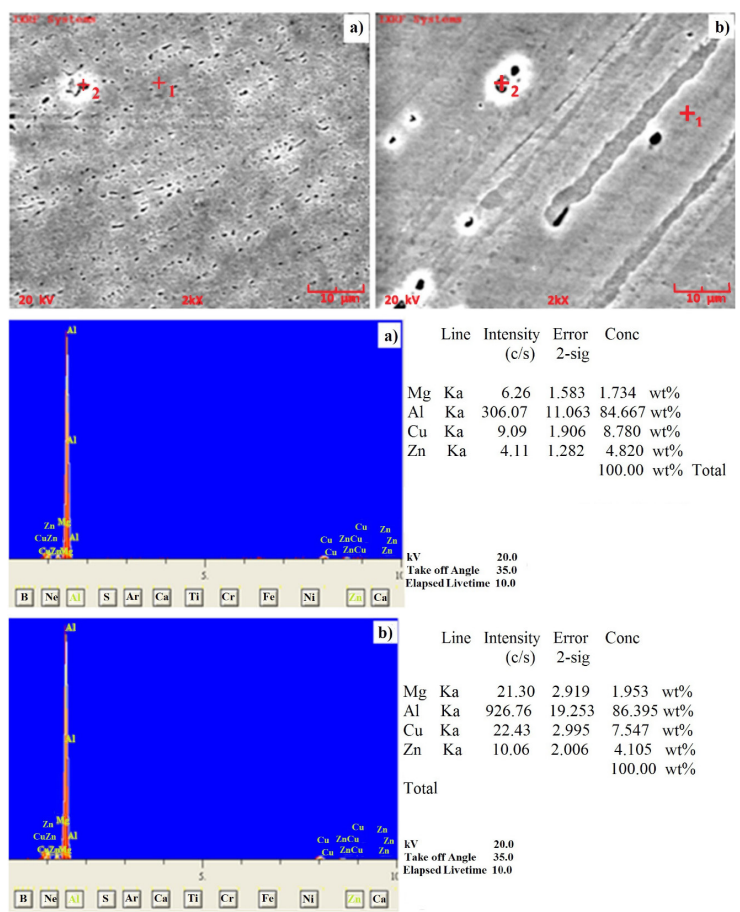

Figure 6. The microstructure of SHTSQ (a) and SHTWQ (b) aged sample at the temperature of $140^{\circ} \mathrm{C}$ for 10 ve 12 hours ageing time. EDS analysis results a) SHTSQ b) SHTWQ. 
as a function of ageing time for SHTWQ and SHTSQ test samples. The given each value is the average of three measurements. An ageing time of -20 and $-10 \mathrm{~h}$ refers to base metal and solution heat treated base metal respectively. The hardness of SHTWQ and SHTSQ test samples was measured as low as 97 and $90 \mathrm{HV}_{5}$ respectively, but a continuous and pronounced increase in hardness with the increase in aging time for $140{ }^{\circ} \mathrm{C}$ is observed as seen in Figure 3 and 4 . The alloy achieves its maximum hardness at $140^{\circ} \mathrm{C}$ when aged for 12 or $10 \mathrm{~h}$. Thereafter, a decrease occurs as the time is increased. An account for increase of the hardness values can be explained by the solubility of $\mathrm{MgZn}_{2}$ that was formed during the T6 treatment, increasing markedly with solution treatment resulting in a higher amount of dissolved $\mathrm{MgZn}_{2}$ in aluminum matrix ${ }^{21-23}$. During quenching, this $\mathrm{Mg}-\mathrm{Zn}$ was kept in a solution. Therefore, the Al phase would contain $\mathrm{Mg}-\mathrm{Zn}$ in a supersaturated solid solution at room temperature. During aging, fine particles of metastable $\eta$ phase formed and precipitated. Thus, the hardness of $7075 \mathrm{Al}$-alloy increases rapidly with artificially aging time.

Figure $7 \mathrm{a}$ and $\mathrm{b}$ show stress-strain diagrams for SHTWQ and SHTSQ test samples aged at $140{ }^{\circ} \mathrm{C}$ for different time intervals. As seen that SHTWQ test samples showed higher strength properties than SHTSQ test samples for all ageing intervals, it could be attributed to the high quenching rate of water in which dissolved precipitates during the solution heat treatment could not find sufficient time to form again. So, the degree of irregularity in the lattices will cause an increase in the mechanical properties of the Al-alloy. The slow quenching rate of sand causes a cooling sensitization in the aluminum alloys.

It is evident that static strain ageing is changing in the $\%$ elongation fracture. As seen in Figure 4, after a solution heat treatment, the elongation fracture value of SHTWQ samples increased but that of the SHTSQ sample decreased.
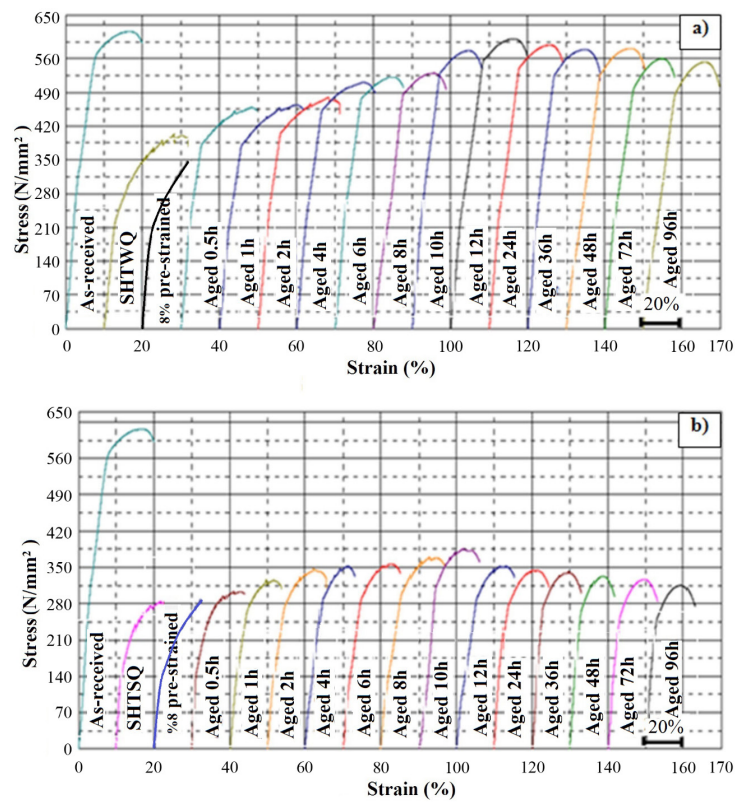

Figure 7. Stress-strain diagram of samples aged at $140{ }^{\circ} \mathrm{C}$ temperature for different ageing times; a) SHTWQ b) SHTSQ.
The reason behind this can be attributed to the cooling sensitization which causes unhardenable coarse precipitates in the aluminum matrix ${ }^{24-26}$. As seen in Figure 8, the EDS analysis from as-received, SHTSQ and SHTWQ samples supported this.

The EDS analysis results shown in Figure 8, indicates the sample cooled especially in sand that contained aluminum and copper rich but magnesium and zinc poor formation as compared with the as received and SHTWQ sample. This result could be evident for cooling sensitization that causes unhardenable coarse precipitates in the aluminum matrix of SHTSQ sample.

Figure 9, shows tensile fracture surface of SHTWQ test pieces when aged at $140{ }^{\circ} \mathrm{C}$ for a period of 2,12 and $96 \mathrm{~h}$ while, Figure 10 shows tensile fracture surface of SHTSQ
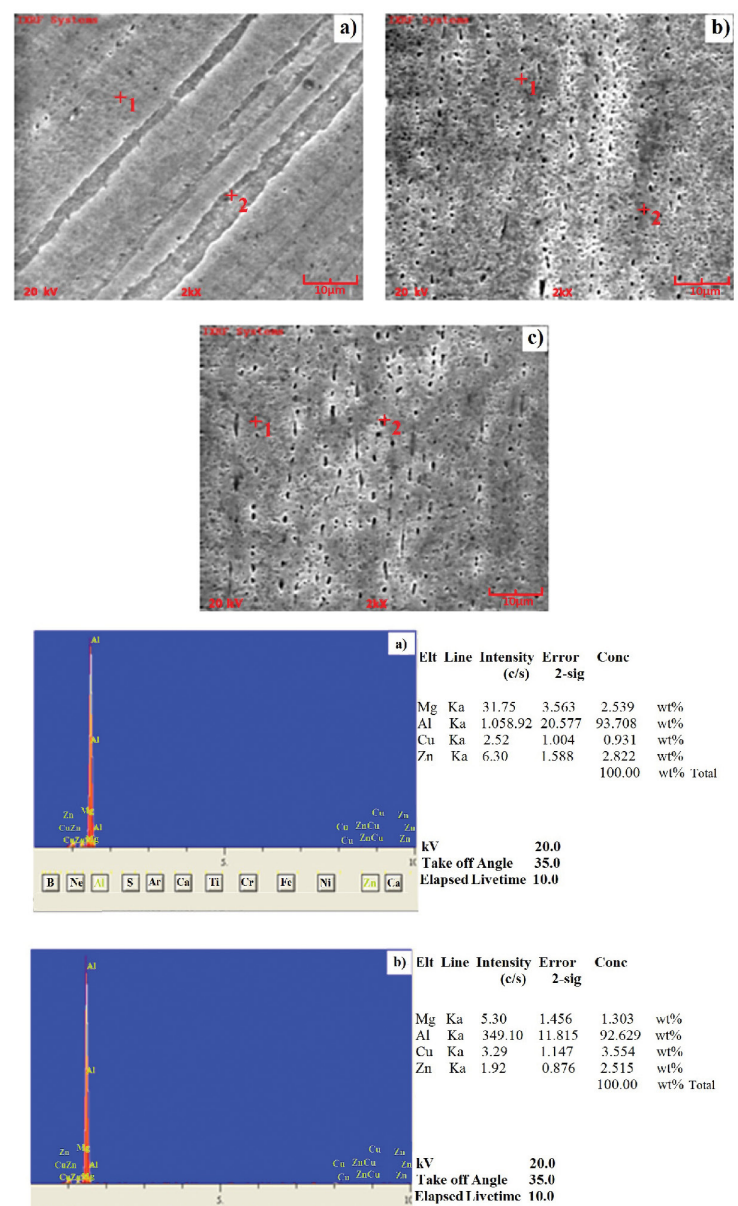

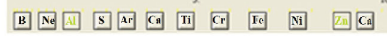

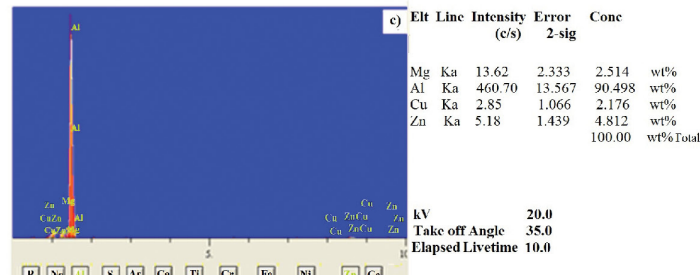

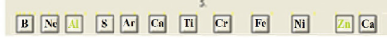

Figure 8. a) The microstructure and EDS analysis of T6 heat treated as-received b) SHTSQ c) SHTWQ 7075 alloy. 

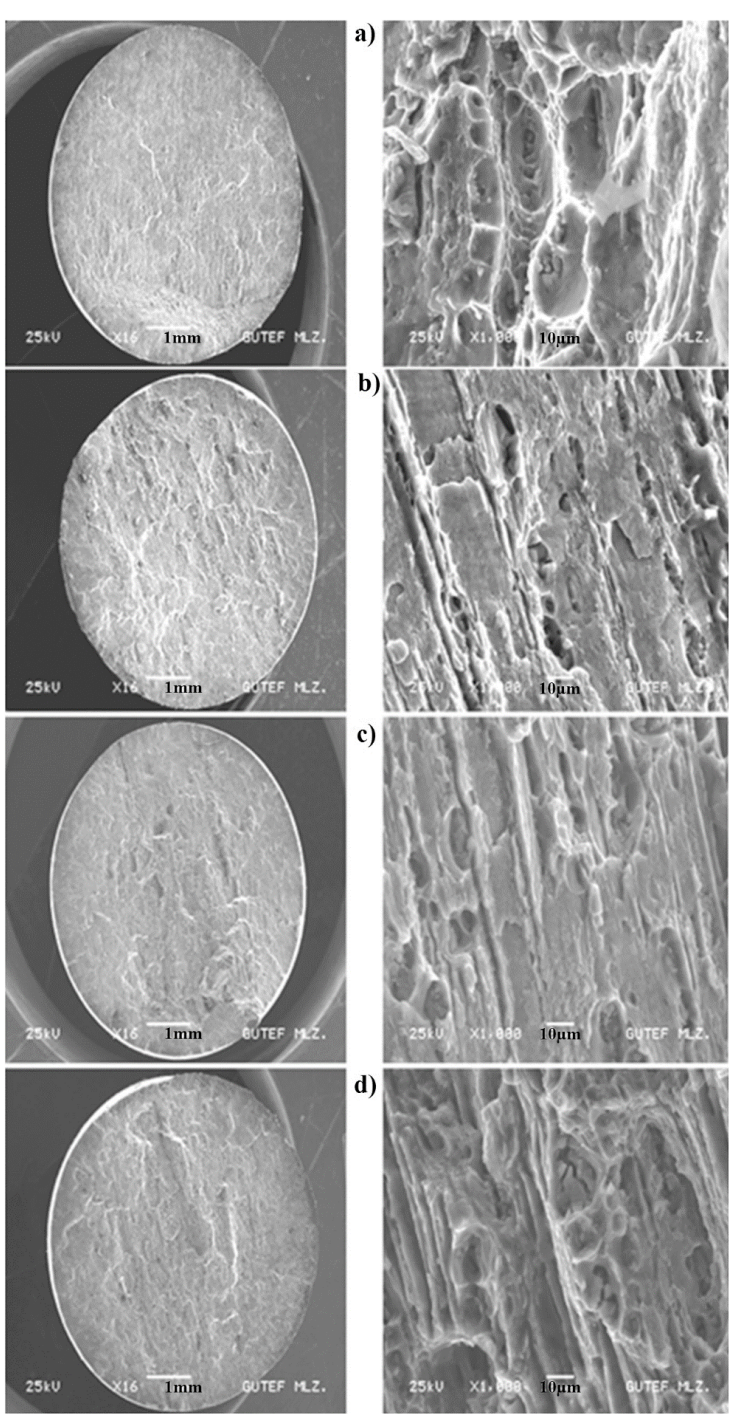

Figure 9. Fracture surface of tensile test samples; a) SHTWQ b) SHTWQ aged $140{ }^{\circ} \mathrm{C}$ for $2 \mathrm{~h}$, c) SHTWQ aged $140{ }^{\circ} \mathrm{C}$ for $12 \mathrm{~h}$, d) SHTWQ aged $140^{\circ} \mathrm{C}$ for $96 \mathrm{~h}$.

test samples when aged at $140{ }^{\circ} \mathrm{C}$ for a period of 2,10 and $96 \mathrm{~h}$. As seen in Figure 9 and 10, SHTWQ and SHTSQ test samples showed dimples and cleavage facets, indicating that the fracture is a mixed type when the alloy was aged at $140{ }^{\circ} \mathrm{C}$ for a period of 12 and $10 \mathrm{~h}$ respectively; this was manifested as low percentage elongation prior to fracture. The reduction in area also decreased at $140{ }^{\circ} \mathrm{C}$ for 12 and $10 \mathrm{~h}$ ageing times, which corresponds to embrittlement due to ageing result of the interaction between dislocation and precipitate particles. However, SHTWQ and SHTSQ test samples showed certain surface roughness typical of ductile fracture and microscopically a surface covered by dimples of several sizes was observed after ageing at $140^{\circ} \mathrm{C}$ for a period of $96 \mathrm{~h}$ which lead to increases in percentage elongation. This causes few obstacles to the movement of dislocations and hence the percentage elongation starts to increase.
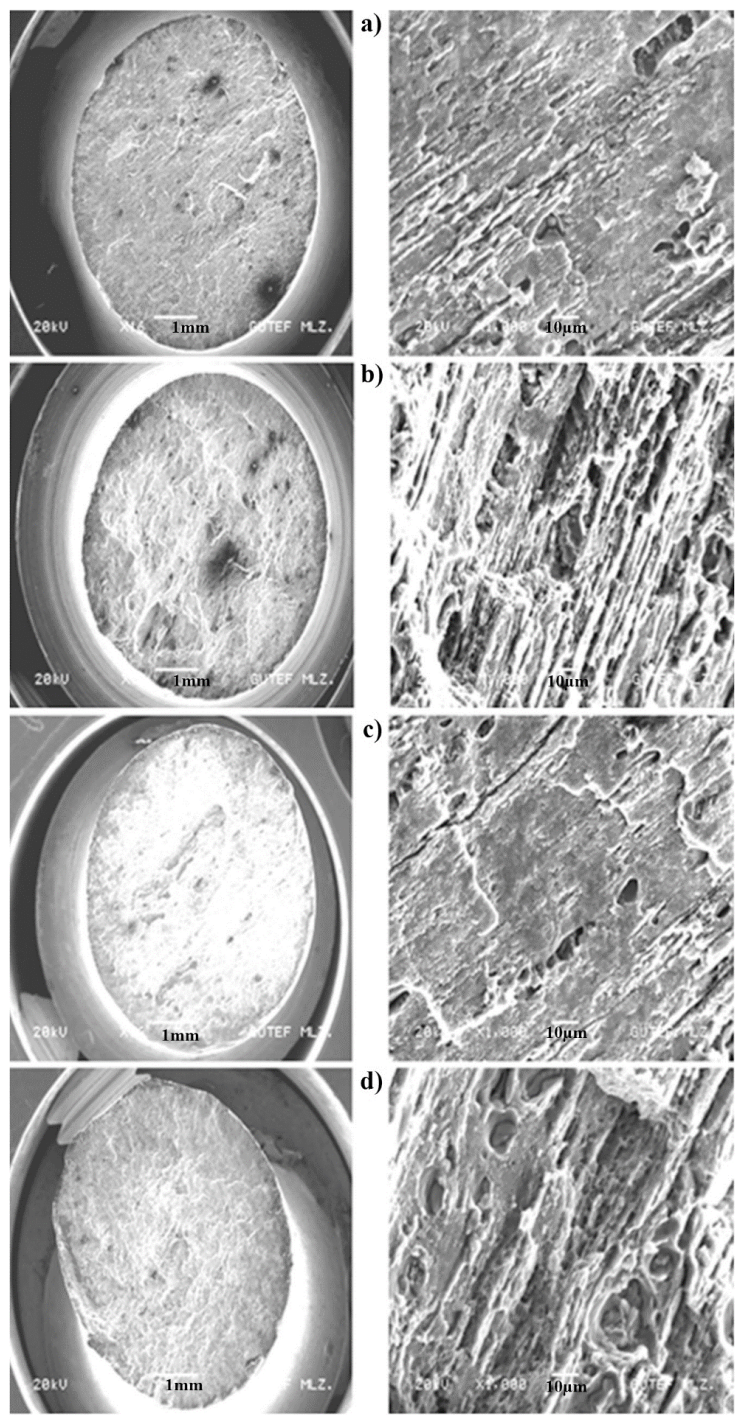

Figure 10. Fracture surface of tensile test samples; a) SHTSQ b) SHTSQ aged $140{ }^{\circ} \mathrm{C}$ for $2 \mathrm{~h}$, c) SHTSQ aged $140{ }^{\circ} \mathrm{C}$ for $12 \mathrm{~h}$, d) SHTSQ aged $140^{\circ} \mathrm{C}$ for $96 \mathrm{~h}$.

\section{Conclusions}

In this work, the aging behavior of SHTWQ/SHTSQ $\& 8 \%$ pre-strained $7075 \mathrm{Al}$-alloy was studied in artificially aged conditions. The conclusions derived from this study can be summarized as follows.

1. The time, temperature, quenching rate and pre-straining plays a very important role in precipitation hardening associated with the ageing of the $7075 \mathrm{Al}$-alloy.

2. An increase in the tensile strength, yield strength and hardness, while a decrease in the elongation fracture of SHTWQ and SHTSQ Al-alloy with increase in aging time for $140^{\circ} \mathrm{C}$ can be explained by a diffusion assisted mechanism. It causes an increase in the density of GP zones, distortion of lattice planes and hindering of dislocation movement by interference with the motion of dislocation, due to the formation of metastable $\eta$ phase precipitates ${ }^{12,20}$. Thus, the hardness 
of 7075 Al-alloy increases rapidly with an artificial aging time.

3. Further increase in the ageing time decreases the tensile strength, yield strength and hardness of the alloy. The stable $\eta$ fazi $\left(\mathrm{MgZn}_{2}\right)$ phase can be responsible for decreases hardening in the overaged sample.

4. SHTWQ test pieces showed higher strength properties than SHTSQ test pieces for all the ageing intervals. This could be attributed to the high quenching rate of water in which dissolved precipitates during the solution heat treatment could not find sufficient time to form again. So, the degree of irregularity in the lattices will cause

\section{References}

1. Williams JC and Starke EA Jr. Progress in structural materials for aerospace systems. Acta Materialia. 2003; 51(19):57755799. http://dx.doi.org/10.1016/j.actamat.2003.08.023.

2. Wloka J, Hack T and Virtanen S. Influence of temper and surface condition on the exfoliation behavior of high strength Al-Zn-Mg-Cu alloys. Corrosion Science. 2007; 49(3):14371449. http://dx.doi.org/10.1016/j.corsci.2006.06.033.

3. Hu H, Yang L, Zhen L, Shao W and Zhang B. Relationship between boundary misorientation angle and true strain during high temperature deformation of 7050 aluminum alloy. Transactions of Nonferrous Metals Society of China. 2008; 18(4):795-798. http://dx.doi.org/10.1016/S1003-6326(08)60137-5.

4. Westermann I, Hopperstad OS, Marthinsen K and Holmedal B. Ageing and work-hardening behavior of a commercial AA7108 aluminium alloy. Materials Science and Engineering A. 2009; 524(1-2):151-157. http://dx.doi.org/10.1016/j.msea.2009.06.036.

5. Temmar M, Hadji M and Sahraoui T. Effect of post weld ageing treatment on mechanical properties of tungsten inert gas welded low thickness 7075 aluminium alloys joint. Materials \& Design. 2011; 32(6):3532-3536. http://dx.doi.org/10.1016/j. matdes.2011.02.011.

6. Demir H and Gündüz S. The Effects of Ageing on Machinability of 6061 Aluminium Alloy. Materials \& Design. 2009; 30(5):14801483. http://dx.doi.org/10.1016/j.matdes.2008.08.007.

7. Hirth SM, Marshall GJ, Court SA and Lyloyd DJ. Effects of $\mathrm{Si}$ on the aging behaviour and formability of aluminium alloys based on AA 6016. Materials Science and Engineering A. 2001; 319-321.

8. Sokolowski JH. Thermoelectric power characterization of a 2024 aluminium alloy during solution treatment and aging. Materials Characterization. 1996; 36(2):83-92.

9. Zhan Z, Ma X, Sun Y, Xia L and Liu Q. The mechanical properties of aluminium alloy by plasma-based ion implantation and solution-aging treatment. Surface and Coatings Technology. 2000; 128-129:256-259. http://dx.doi.org/10.1016/S02578972(00)00585-5.

10. Kumar KS, Brown SA and Pickens JR. Microstructural evolution during aging of an A-Cu-Li-Ag-Mg-Zr alloy. Acta Materialia. 1996; 44(5):1899-1915. http://dx.doi.org/10.1016/13596454(95)00319-3.

11. Bekheet NE, Gadelrab RM, Salah MF and Abd El-Azim AN. The effects of aging on the hardness and fatigue behaviour of $2024 \mathrm{Al}$ alloy/SiC composites. Materials \& Design. 2002; 23(2):153-159. http://dx.doi.org/10.1016/S0261-3069(01)00072-3.

12. Sha $\mathrm{G}$ and Cerezo A. Early-stage precipitation in $\mathrm{Al}-\mathrm{Zn}-\mathrm{Mg}-\mathrm{Cu}$ alloy (7050). Acta Materialia. 2004; 52(15):4503-4516. http:// dx.doi.org/10.1016/j.actamat.2004.06.025. an increase in the mechanical properties of the Al-alloy. It is foreseen but not proved that the slow quenching rate of sand causes a cooling sensitization which causes unhardenable coarse precipitates in the aluminium matrix. Pre-straining may also lead to deformation hardening and thus gives a rather high strength.

5. Fractographic analysis showed that SHTWQ and SHTSQ Al-alloy underwent brittle and ductile fracture when aged at $140{ }^{\circ} \mathrm{C}$ for 12 and $10 \mathrm{~h}$ respectively. In the case of increasing ageing time of $96 \mathrm{~h}$ for $140^{\circ} \mathrm{C}$, the fracture pattern changed from a moderate ductile to a ductile nature.

13. Wang D, Ni DR and Ma ZY. Effect of pre-strain and two step aging on microstructure and stress corrosion cracking of 7050 alloy. Materials Science and Engineering A. 2008; 494(1-2):360366. http://dx.doi.org/10.1016/j.msea.2008.04.023.

14. American Society for Testing and Materials - ASTM. ASTM E8M-09: test methods of tension testing of metallic materials. West Conshohocken; 2009. v. 3.01.

15. Siddiqui RA, Abdullah HA and Al-Belushi KR. Influence of aging parameters on the mechanical properties of 6063 aluminium alloy. Journal of Materials Processing Technology. 2000; 102(1-3):234-240. http://dx.doi.org/10.1016/S09240136(99)00476-8.

16. Cristoffer F. Accelerated ageing of aluminium alloys. [Dissertation]. Karlstad University; 2009.

17. Cassada WA, Shiflet GJ and Starke EA. Mechanism of Al2CuLi (T 1) nucleation and growth. Metallurgical Transactions. A, Physical Metallurgy and Materials Science. 1991; 22(2):287297. http://dx.doi.org/10.1007/BF02656798.

18. Cassada WA, Shiflet GJ and Starke EA. The effect of plastic deformation on $\mathrm{A} 12 \mathrm{CuLi}$ ( $T 1$ ) precipitation. Metallurgical Transactions. A, Physical Metallurgy and Materials Science. 1991; 22(2):299-306. http://dx.doi.org/10.1007/BF02656799.

19. Kim JD and Park JK. Effect of stretching on the precipitation kinetics of an Al-2.0Li-2.8Cu- $0.5 \mathrm{Mg}(-0.13 \mathrm{Zr})$ alloy. Metallurgical Transactions. A, Physical Metallurgy and Materials Science. 1993; 24(12):2613-2621. http://dx.doi.org/10.1007/BF02659485.

20. Mukhopadhyay AK, Yang QB and Singh SR. The influence of zirconium on the early stages of aging of a ternary $\mathrm{AlZn} 2 \mathrm{Mg}$ alloy. Acta Metallurgica et Materialia. 1994; 42(9):3083-3091. http://dx.doi.org/10.1016/0956-7151(94)90406-5.

21. Edwards GA, Dunlop GL and Couper MJ. In: Proceedings of the 4th International Conference on Aluminium Alloys; Atlanta, GA. 1994. p. 636. v. 1.

22. Gupta AK and Lloyd DJ. In: Proceedings of the 3rd International Conference on Aluminium Alloys; Trondhiem, Norway. 1992. p. 21. v. 2.

23. Bray GH, Glazov M, Rioja RJ, Li D and Gangloff RP. Effect of artificial aging on the fatigue crack propagation resistance of 2000 series aluminium alloys. International Journal of Fatigue. 2001; 23:265-276. http://dx.doi.org/10.1016/S01421123(01)00159-1.

24. Gamble BM, Csontos AA and Starke EA. A quench sensitivity study on the novel Al-Li-Cu-X alloy. Journal of Light Metals. 2002; 458:265-275.

25. Liu SD. Influence of aging on quench sensitivity effect of 7055 aluminium alloy. Materials Characterization. 2006. http:// dx.doi.org/10.1016/j.matchar.2006.10.1019.

26. Totten GE, Webster GM and Bates CE. Quenching. Handbook of Aluminium. New York: Marcel-Dekkar; 2003. p. 881-970. 